\title{
13. \\ HOW TO USE CULTURAL HERITAGE \\ FOR RECONCILIATION
}

\section{Tomislav Šola}

UDK: 316.7:572

ractice is always a description of reality and its obvious potentials. Theory is about positions and conditions we want to achieve. When understood properly, its departure is practice and its goal is practice. While practice moves through stages of perfection, theory navigates it by reading the context, setting its nature and purpose. Without theory, practice is reduced to learning by tries and mistakes. The moment the practice gets reflective quality, an ability of abstraction and generalization, quality of projecting - it is more than practice.

Peace is just one of the innumerable positive, constructive phenomena that heritage institutions, museums included, can serve. As powerful accumulation of evidence, information and knowledge, heritage institutions are meaningful only if they use their potential for the benefit of common good. As tools of selected, collective memory, they can go as far as producing wisdom instead of mere information and knowledge. Their immense power of unbiased communication can, therefore become decisive means of democracy. True peace is the consequence of ennobled mind, but to become such, the mind needs arguments and advice. No public institutions than those of heritage are better equipped to provide help to troubled and bewildered citizens of the present world when about the quality of their lives. Peace is the basic one.

The best that most of museums can do for peace, and all can, is to affirm, promote, generate political literacy; politically literate are unlikely to become manipulated mass - the matter of warfare.

\section{What does theory do?}

Practice is always a description of reality and its obvious potentials. Theory is about positions and conditions we want to achieve. When understood properly, its departure is practice and its goal is practice. While practice moves through stages of perfection, theory navigates it by reading the context, setting its nature and purpose. Without theory, practice is reduced to learning by tries and mistakes. The moment the practice gets reflective quality, 
an ability of abstraction and generalization, quality of projecting - it is more than practice. Peace is just one of the innumerable positive, constructive phenomena that heritage institutions, museums included, can serve. As powerful accumulation of evidence, information and knowledge, heritage institutions are meaningful only if they use their potential for the benefit of common good. As tools of selected, collective memory, they can go as far as producing wisdom instead of mere information and knowledge. Their immense power of unbiased communication can, therefore become decisive means of democracy. True peace is the consequence of ennobled mind, but to become such, the mind needs arguments and advice. No public institutions than those of heritage are better equipped to provide help to troubled and bewildered citizens of the present world when about the quality of their lives. Peace is the basic one.

The general theory of heritage, heritology, to make it simple, has the purpose in becoming the philosophy of the heritage profession(s), in providing critique of theory and practice, sets the content and methodology of transfer of the professional experience, foresees and projects professional future and establishes the relation of heritage professions towards the development.

\section{The peace and its nature}

In the socio-political chemistry what we strive for is the harmonious stability of divergent elements in which violent reactions would simply have no chance. Agreements, treatises of alliance, ceasefires and laws are not enough.

Peace depends upon conditions provided. The first condition is the honest prosperity based on the fair division of common wealth. Obscene wealth should be a social sin as its worst effect is constant production of inequality and conflict. It cultivates Greed and provides growing legitimacy to it. Existence of injustice and dominance deny the very possibility of peace.

Most of the world will experience no wars in the usual, historical way. The state of "munus omnia contra omnes" - the fight of all against all. Our streets are becoming the fighting filed all too often and the "war" of the groups against others is frequent. We see that minorities of radical orientation be it about fur-coats or diet can truly molest the majority. The clashes will be increasing very much by the growing accumulation of despair, loneliness and aggression in individuals. Those will surely form the dangerous phalanges and produce unrest. In brief, war is becoming the daily reality: less dramatic because dispersed, but ruining the quality of life nonetheless.

Peace is one of the pillars of democracy. It is the outer form of natural and human rights exercised. It can flourish only upon the, responsible choices in development, civil insight and transparency of societal, developmental and political processes, unbiased information, rich cultural life and unbiased information. Democracy is utopian and does not exist. Only tries to have it do. So peace as quality of living is a precondition to democracy and prosperity. The scared and suffering are an easy prey to dictatorship and enslavement of all sorts.

Peace is the way of thinking, a quality of human condition. The culture of peace is founded upon the system of values in which the constructive, creative and emphatic qualities of human genius are part of the matter of reason and common sense. Being different 
and of different attitude should be aberrant and deficient, as nothing that produces despair, discomfort, conflict and poverty can be regarded as humanly acceptable. So, peace is possible in the world where it presents the priority and true aim. But, peace is not the priority of the world we live in.

\section{Wars are for the poor devils}

When about richness distributed, almost all of it goes to the rich. When misery and wars are distributed globally, the poor get all of it. Classical wars will be exported/or implanted in the third world where resources have to be conquered for the ever more avaricious and greedy corporations. Therefore we live in the world where peace needs to be defended daily and where peacemakers are constant losers. Wars are everywhere. The troubled history will take time to settle and correct what needs to be corrected. Wars are politics gone mad. Anything can be an excuse for war. If there isn't any - well it can be created. War is an export product easy to sell: there's always somebody to embrace the project and many to take part in the feast.

Museums and other institutions of collective memory could be of some use for peace. They are already.

If terrorism is an excuse - so much the better. Otherwise the world we have inherited would have no basis for the repression: a picture of an impossible world!

\section{The warring world we have}

By the nature of the world we shall be inclined to CONQUER as much and as far as we can reach. Saying "we", is rather inaccurate, as most humans are not interested to interfere with anything which is beyond our immediate life environment or, in the other extreme, beyond the stratosphere. (Why would anybody spend billions on space research while we have so much to do and spend on the world so badly in the need). So, who are "them"? Preponderant forces of the society, world leaders, the NSC (when about the accumulation of power), IMF, WTO, multinational corporations... Another paranoia? Not really, because their own documents clearly assume the responsibility and ambition: they do want to lead the international community and they feel responsible for it. The only difference is that they want us to say how happy we are with this fact and how democratic all this is. If one has difficulties to utter that, one is either anarchist or communist, as it suits their moment.

We, the citizens of the world are deceived. The century old doctrine that saw peace as the result of balance of power was useless when it was there (Francis B. Sayre). Why are we tortured again by the remaining imbalance?

They wars can be subtly manipulated business that hardly ever appears in history textbooks and museums. If not directly, an invasion can always be done from within the country: like English did in Sudan by using Egyptian soldiers and French money, or Russians in Poland, or indeed, America in so many places that they cannot remember them any more. Direct exports of war as mere conquest is an endless sequence of evil that constitute 
the world of today. Curiously, the most powerful countries are the greatest sinners in their past and these stories are "little else than a long succession of useless cruelties" (Voltaire about History).

In the world in which military investment is hundred times bigger than that for culture and noble causes like arts, - we only have what we invest in: lot of wars and proportionally more destruction and misery and. No God of ours that we pray to, approve that - and we all know it. But most of the wars are fought in gods' name and with priests' blessings. We live in the greatest era of hypocrisy in human history. UN has become alibi provider for those in it who are powerful enough to put veto on undeniable, or manipulate decisions by financial blackmailing. Of course, there is nothing new about it: Might makes right. Anything positive is always more demanding. Aristotle said: "It is more difficult to organize peace than to win a war". And, as ever, the responsibility is always with power.

\section{Homo homini lupus, or how are we manipulated to chaos}

Greed as the only remaining ideology is proposed and praised: the public hullabaloo in the meantime drums incessantly about human rights, all sorts of rights, making us all live at daggers drawn.... Individuals are given the illusion of importance by suggested total freedom of individual claims. But, try the substantial! Tied to the working place, reduced to working skill on the market, scared by insecurity, robbed by the banks and brainwashed by the media, contemporary person is a destitute serf in modern feudalism. Those who refuse the exhausting daily toil in total insecurity and deny happy consumerism will end up in hospitals and asylums, with destroyed marriages, destructed families, broken friendships... Thus individuals become separated by interests and find themselves completely alone. From there on - the Great Greed Force has another lump of clay to build its instrumentalized Golem - the Machine as Lewis Mumford would put it.

Behind the democratic scenery, there is a mastodontal global project of creating the billions of scared, lonely individuals that will willingly find the shelter in the parades of collective ego and become the happy inhabitants of the Planet Hollywood - a vision common to any totalitarian scheme. "Democracy" is one of the most frequently used words of today: the first proof it does not exist. The citizen is turned into a shopper of dreams and illusions. He/she is stuffed and grind by media with daily portions of soma, kept busy buy insecure existence and incessant competition, entangled by loan sharks (who, in Europe at least, used to the banks in service of community)...

The expectation of the creators of it is that we will not notice what is happening as danger seemingly died away by the fall of the Berlin wall. And, they just might be right. So you will neither notice the planetary shame of legal trade with the right to pollute; or - that the multinationals of the first democracy in the world caused the last two dozens of wars on the very same and only Planet.

When you start believing that smoking is the worst problem of mankind and that lives of white mice are question for to be or not to be, then you are part of the mass.

The only possibility is the organized citizen. But the citizen must be educated enough and informed enough not only to look but to SEE. Will our institutions help? Will professions stay faithful to their plot against laity, a temptation Bernard Shaw signaled so long ago? 


\section{What can heritage institutions do for peace?}

Military, war and museums alike, for the most and still quite horrifying and disgusting places, sort of manipulated reconstructions of crime scenes. Their scientific background may be correctly done but who made the choice? What if "events in the past may be roughly divided into those which probably never happened and those which do not matter" (W. R. Inge). What if generalized history is indeed "a branch of speculation, connected (often rather arbitrarily and uneasily) with certain facts about the past" as Aldous Huxley claimed?

Tens of thousands ambitious, scientific and expensive museums glorify the warriors, generals or imperators. We passed through a long succession of "useless cruelties" (Voltaire about history) and hardly any museum admits any guilt. Servile to their bosses and autistic in their community, they show but glorious, rightful armies and their wicked enemies. We glorify generals, murderers and plunderers, but hardly any of the peace makers: it seems our museums tacitly consider them traitors.

Taken as a whole, museums hardly record the human epopee of suffering, and if they do it is often one side of the story. They rather praise conquest and victories as triumphs of the national strength.

Who caused then such a terrible suffering on this Planet? Who made it a place of continuous slaughter? Can each nation and each community finally take up their blame and, being purged by the truth, continue by being better? In museums? Hardly. Disturbing memories might cause unwanted effect ${ }^{1}$. Elsewhere? Not probable. When politicians, priests and educators talk the language of intolerance and hatred, the country will know no peace; anybody different or any difference will be the good enough enemy. But, maybe, finally, there would be the time for the red line and different continuation? Museums will not change the world but may help in making this change possible.

"Peace is not the elimination of the causes of war. Rather it is a mastery of great human forces and creation of an environment in which human aims may be pursued constructively". (James H. Case, Jr. ). It "is not absence of war, it is virtue, a state of mind, a disposition for benevolence, confidence, justice" (Baruch de Spinoza).

Telling stories of importance of peace is dull and uninteresting. But presenting the eternal values of justice, freedom and prosperity that constitute the peace can be quite intriguing. It is values that make the peace possible as the one that comes out of mere war exhaustion is neither timely nor enduring. Museums cannot change the world but they can help towards making it better by sowing the love in place of hatred, pardon instead of injury, union instead discord, faith instead of doubt, hope instead of despair, light instead of darkness, joy where sadness is (paraphrase of St. Francis of Assisi). One should question the use of history museums as a whole, at least to find out the positive examples and praise them as the way onwards. There are more and more of them, to tell the encouraging news.

The heritage institutions have to propose attractive ways of explaining that the sure way to hell is the growing apotheosis of egotism. Peace is not the set of rules and agreements. It is quality of culture and a state of mind. If heritage institutions cannot teach qualities that mean peace or set ground for it, then they are dead capital - misused and buried. The mere knowledge amassed in the immense quantity of evidence they keep in their vaults or expose

1 The Enola Gay case, where profession lost by the Director of the Museum being fired. 
in their galleries is impressive enough for that. If taken as material for wisdom, this collective memory is worth the effort. It becomes truly meaningful. Why on Earth should the collections exist if they cannot remind us, teach us that 90 billion people died so far on the Planet and that most of them knew what was wrong and disgraceful in human existence: the incessant killings and destruction instead of love, compassion, comfort and prosperity?

Peace themes are dull and uninteresting: tautological, patronizing, disciplined, educational, unattractive... But, tell the interesting story! In some foreseeable future, when we build up a strong profession of heritage communicators and careers, we shall probably still have enough public money to demonstrate that we are not just passive scribes to the masters of the history, but also partakers in it - those who use knowledge to provide the usable answers to our fellow beings. Internet is the apotheosis of knowledge. But as mountains of knowledge grow endlessly, as we drown in the ocean of the useless information - we seem to have less and less wisdom. Can curators tolerate it infinitely? Can intellectuals be calmed forever? We shall be losing our public jobs and having walls build around us only if we are just few, if we do not represent a profession. We do not want to become a political party. We do not want to offer the sole and only truth. We do not require the privilege of obedience. What we do have to offer is the entire truth, all sides of it, timely, useful, ethical and responsible - referring to the obvious problems of our taxpayers and users.

In the panopticum of illusions and deceptions, we, ordinary people are puzzled and frightened. What is what and who is who, indeed? We are attacked by the armies of scoundrels of all sorts, no matter what title or position they disguise themselves in. All of them fight either for our mind or valet or both, indeed and use an array of techniques to swindle our minds and our perceptions. The reasons are always the same: power and gold in all shapes, colors and alloys.

Heritage institutions should be like grandfathers, old uncles, wise grandmothers knowledgeable and experienced friends who help us re-gain control of our mind and senses. They would tell us stories of the experiences stored into their vaults, stories about the human nature and its temptations, about traps and enemies, about ways to freedom and harmony. They have to teach us what is true and what is false, what is beautiful and why - in brief how to recognize virtues, how to possess them and how to enjoy their blessing. We do not need them as hermetic philosophers but as simple wise men, able to guide us through our own world: our schools, our shopping malls, our jobs, living ambiences, natural environment, politics, media and places of interest... All these places and activities need to be interpreted to be fully and correctly understood. Schools can do much, but we need a genuine learning environment - that what we so eagerly and idealistically expected from television. 28 hours of TV program that an average American consumes a week, is rarely more than bubbles in the Coke: the nothing that became new epitome of reality. Freedom is being able to live and think autonomously and decide for one self. Individualism is the future cut to measure of any human being, and not the horror of total loneliness as it is daily projected. The Great Greed turns humans into insecure addicts who fly from freedom and fall prey of collective hysteria. 


\section{Heritage as the Art of Bridges Maintenance}

Heritages were always the domain of very intensive activity: the further they were pushed towards the future and the more they were exposed to the "civilization" the more they became a projection of collective self. Knowing what we want to be in the future, changes the "us" from the past so that we can also claim qualities in the present that otherwise would not have legitimacy: past would deny it and future would refuse it. So we have built museums to make our project of heritage engineering solid and indisputable. Not all was wrong. By no means! Curiosity, research, classification, knowledge and the chance to love when you know your object of love - all that was positive and offered lot of chances which were pre-calculated profit by the enlightened few and side effect by the rest. New reading of the past? Nonsense, the later might exclaim: the past is defined. Apparently, we can only correct it in as much as the governing forces of the society change and, as they change their priorities.

Heritages where thus the battlefield of identities. Many wars were fought over them: their definitions, claimants, territorial spread....The stronger would engulf and subordinate the weaker. The wisdom thus forgotten was that any variety was a blessing, not a curse. Only losers, as we are all now, get the chance to see the fact clearly, but probably too late.

Instead of seeing heritages as figures in the power game, it is possible (theoretically, only?) to see them as richness to enjoy. Knowing them may have served as bridges between the differences: ways of communication and exchange. But modern society was built upon the ideology that any difference is potential danger and presents an obstacle to the conquest. The conquest was, namely, the name of Occidental relation to the world as whole and to its parts. I conquer, therefore I grow, which means that I am progressing, assuring longevity to anything I stand for. So we have made a culture of walls instead of roads. That other was a potential danger or the resource of power if conquered or resistance and refusal if fighting back. The different other was taken as the unknown, and the unknown is either feared or wiped out. Globalization was always there but once it demonstrated its monstrous power of irreversible destruction of all the values by their mere commodification, subordinating them to the obsession for the quickest and greatest profit - we started to contemplate and, maybe, understand the world differently. Paradoxically, tourist industry which is profit driven and heritage sector driven by mission, found themselves at the same side of barricade though not as friends: sustainability means keeping resources renewable and alive, and any longer strategy cannot do without it.

Knowing the other is already a bridge built so be it inclusion or integration or just being wide enough to be what one is, while allowing the other to do the same - is a bridge built. As a philosopher said, only the bridge over a river makes the banks recognize their difference. Much can be done along this visionary truth and some things are done indeed....

\section{Heritage tourism for community development}

The lecture itself will partly fall out of the frame of the conference and, but organizers graciously agreed. However, I feel like contributing more to the theme of peace and its 
linkage to culture and tourism. Practicing culture, let alone tourism is impossible without peace. The precondition for culture is peace as there is no culture agreeing to war. Culture and war are opposed by definition. Peace is not only the absence of armed conflict; it is also peace of mind, cultured life and prosperity, all that we are losing on the global scale. For the lucky part of the world, state of war is "just", acculturation and entropy in all its forms. The world is becoming uglier, unsafe, unfriendly, poorer, more aggressive, its food, air and water poisoned, its heritage endangered, traditions destroyed... And all that by the will and for the profit of the few. Tourist industry, at its worst, is part of these devastating forces. It is a very demanding industry, giant spendthrift, usually careless about the consequences. We have arrived at the point when a new deal has to be struck in which the owners of the industry will have to invest part of their profit into the maintenance and regeneration of the resources. In most cases of cultural and heritage tourism, we witness violent exploitation, quite a rape of local values. The time of avoiding strong words has expired as this "war" is real. During the last few decades the frontline has reached our heritage institutions. Turning your head away because you may end up in bad relations with the ruling elite becomes a feeble excuse our public will not tolerate. John Adams said: "There are two ways to conquer and enslave a nation. One is by sword. The other is by debt". We have unfortunately learned the third: acculturation. That process mirrors the essence of the relation between tourist industry and peace. We are being deprived of prosperity in the blessed richness of our cultural differences and variety of our nature. Paradoxically, these are the very qualities the tourism itself is founded upon. Once the resources are exhausted tourist industry moves on. But hosts stay. And just to add: development is about quality of life, not earning ever more money (for the rich).

\section{Conclusion}

Anatole France thought, like many, that universal peace will be realized because it will be imposed by "new order of things, a new science, new economic necessities". The future is likely to become a constant denial of peace qualities. Wars will be rare as the resources all over the world become either conquered or privatized and re-sold to corporations. But the unrest, conflict, and terrorism will be the daily practice of a war as social and political state. The Great Greed Forces will take it as a further excuse to limit the freedom.

Once the daring and adventurous human spirit is orientated towards the inner explorations, of which art is the best example - the mankind may count with chances of survival, both in the sense of upgrading of human nature and that of harmonious, sustainable development. That, however, is a distant and rather improbable variant as human nature will remain an easy prey to its fatal enemies. Petrarch counted five of them: avarice, ambition, envy, anger and pride.

We look forward to the time when Power of Love will replace the Love for Power (William E. Gladstone). Losers or winners, we have no choice but to build our edifice of virtue as societal project. I am a convinced pessimist but humankind has survived so far just because we never learned to give up. This terrible shortcoming is also our chance. 


\section{$\cos$}

\section{Literatura $i$ izvori}

Broz, Svetlana. 2005. Good People in an Evil Time: Portraits of Complicity and Resistance in the Bosnian War. New York: Other Press.

Citroni, Gabriella. 2011. Gross Human Rights Violations and the Preservation of Historical Memory in Latin America. Research paper presented at the Geneva University of Art and Design, Geneva.

Gegner, Martin i Bart Ziıno. 2012. Heritage of War. New York - London: Routledge Chapman \& Hall.

Halbwachs, Maurice. 1925. Les cadres sociaux de la mémoire, Paris: Presses universitaires de France.

Hazan, Pierre. Chantiers contre charniers, Le Temps, 6 juillet.

Hinton Laban, Alexander, ur. 2002. Annihilating Difference: The Anthropology of Genocide. Berkeley; University of California Press.

International Coalition of Sites of Conscious, http://www.sitesofconscience.org/about-us (pristup 15. 5. 2014.)

International network of museums for peace, http://peace.maripo.com/p_inmp.htm (pristup 20. 5. 2014.)

Kattan, Emmanuel. 2002. Penser le devoir de mémoire, Paris: Presses universitaires de France.

MacDonald, Sharon. 2008. Difficult Heritage: Negotiating the Nazi Past in Nuremberg and Beyond. Hoboken: Taylor \& Francis.

MacDonald, Sharon. 2013. Memorylands: Heritage and Identity in Europe Today. New YorkLondon: Routledge.

Memory, History and Monuments, the Aschrott-Brunnen Fountain, http:/www2.facinghistory.org/ campus/memorials.nsf/0/64A4BBBE53CEC43C85256FAA006C809F (pristup 15. 5. 2014.)

Peace Museum Vienna, http://peacemuseumvienna.com/wp-content/uploads/2013/03/Towards_a_ Global_Peace-Museum_Movement.pdf (pristup 15.5.2014.)

Ramel, Sylvie. 2005. Reconstruire pour promouvoir la paix? Le cas du "Vieux Pont" de Mostar, Genève: Université de Genève.

Šola, Tomislav. 1985. Antimuzej: bibliofilsko izdanje. Zagreb: Zbirka Biškupić.

Šola, Tomislav. 1989. Role of museums in developing countries. Varanasi: Bharat Kala Bhavan Hindu University.

Šola, Tomislav. 1990. “The Museum Curator: endangered species”. U Museums 2000, ur. Patrick Boylan. London: Association Routledge, 152-164.

Šola, Tomislav. 1991. Museums and Curatorship: the role of theory. U The Museum Profession, ur. Gaynor Kavanagh. Leicester: Leicester University Press, 125-137.

Šola, Tomislav. 1992. "The European Dream and Reality of Museums: a report from South-East”. U Museums and Europe 1992, ur. Susan Pearce. London: The Athlone Press, 159-173.

Šola, Tomislav. 1997. Essays On Museums And Their Theory: towards the cybernetic museum. Helsinki: Finnish Museums Association.

Šola, Tomislav. 1997. "Museums, museology, and ethics: a changing paradigm”. U Museum Ethics, ur. Gary Edson. London: Routledge, 168-175.

Šola, Tomislav. 1997. “The role of Museums in Sustaining Cultural Diversity”. U Cultural Traditions in Northern Ireland: cultural diversity in contemporary Europe, ur. Maurna Crozier i Richard Froggat. Belfast: The Institute of Irish Studies, 107-113. 
Šola, Tomislav. 2001. Marketing u muzejima ili o vrlini i kako je obznaniti. Zagreb: Hrvatsko muzejsko društvo.

Šola, Tomislav. 2002. Marketing u muzejima ili o vrlini i kako je obznaniti. Beograd: Clio.

Šola, Tomislav. 2003. Eseji o muzejima i njihovoj teoriji-prema kibernetičkom muzeju. Zagreb: Hrvatski nacionalni komitet ICOM.

Šola, Tomislav. 2009. De la vanitat a la saviesa / From Vanity to Wisdom. Girona: Institut Catala de Recercs en Patrimoni Cultural.

Šola, Tomislav. 2011. Prema totalnom muzeju. Beograd: Centar za muzeologiju i heritologiju.

Šola, Tomislav. 2012. Eternity does not live here any more - a glossary of museum sins. Zagreb: Vlastita naklada.

Šola, Tomislav. 2014. Javno pamćenje - čuvanje različitosti i mogući projekti. Zagreb: Zavod za informacijske studije, Filozofski fakultet Sveučilišta u Zagrebu.

Šola, Tomislav. 2004. "Redefining collecting". U Museums and the future of Collecting (Second Edition), ur. Simon J. Knell. Aldershot: Ashgate Publishing Limited, 250-260.

ŠolA, Tomislav. 2004. "The importance of being wise or could "Museum archaeology" help us be better professionals”. U Archeologia del museo, ur. Fiamma Lenzi I Andrea; Zifferero. Bologna: Editrice Compositori, 11-16.

Šola, Tomislav. 2009. "Baština kao poziv i društveno opredjeljenje”. U Ivi Maroeviću baštinici u spomen, ur. Žarka Vujić i Marko Špikić. Zagreb: Zavod za informacijske studije Odsjeka za informacijske znanosti Filozofskog fakulteta Sveučilišta u Zagrebu, 111-138.

Šola, Tomislav. 2009. “Towards the Total Museum”. U Museums in a Digital Age, ur. Ross Parry. London: Routledge, 421-426.

Šola, Tomislav. 2010. “The Museum Definition: Questioning the Scope and Motives”. UWhat is a museum?, ur. Ann Davis, André Desvallées i François Mairesse. Munchen: Verlag Dr. C. Mueller-Straten, 106-112.

Šola, Tomislav. 2010. "European Collection Resources - museums serving European identity". U Encouraging Collections Mobility - A way forward for museums in Europe, ur. Susanna Pettersson. Helsinki: Finnish National Gallery, 248-257.

Šola, Tomislav. 2011. "Virtues and Qualities - a contribution to professionalizing the heritage profession”. U The Best in Heritage, ur. Tomislav Šola. Zagreb: European Heritage Association, $10-21$. 